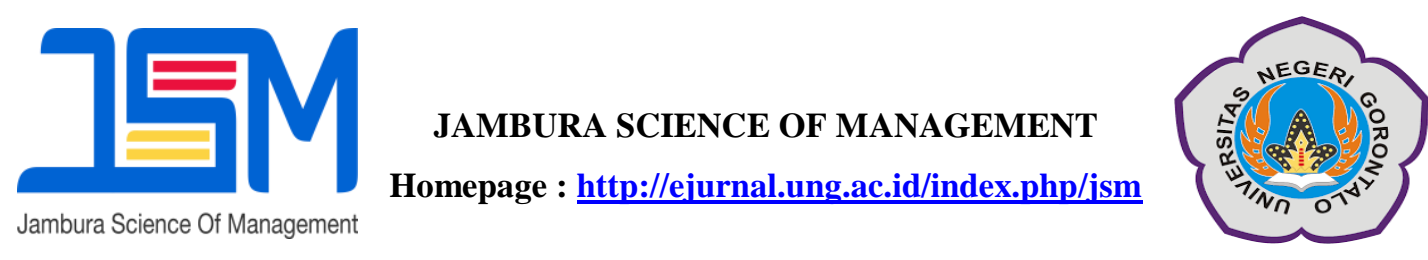

\title{
The Effect of Education and Training on Employee Performance at PT. PERTAMINA (persero)
}

\author{
Lisda L Asi ${ }^{1}$, Vatra Ayu Cahyani ${ }^{2}$ \\ ${ }^{12}$ Department of Management, Economic Faculty, Gorontalo State University \\ E-mail:Lisda@ung.com
}

\begin{abstract}
:
The research objective was to find out to what extent the effect of education and training on employee performance at PT. PERTAMINA (persero) Fuel Oil Terminal of Gorontalo. The data collection was performed by distributing a questionnaire to respondents who have met the standard of the determined sample hence the research data were classified as primary data. The research samples were 30 people. The data were obtained from observation, interview, questionnaire, and documentation. Then, the data analysis used simple linear regression through the assistance of SPSS version 22 program. The findings of research showed that the value of determination coefficient $\mathrm{R}^{2}$ was 0,314 and it signified that $31,4 \%$ of employee performance at PT. PERTAMINA (persero) Fuel Oil Terminal of Gorontalo was affected by Education and Training program conducted by the company. Meanwhile, the rest employee performance for $68,6 \%$ was probably affected by other variables such as the compensation system, work culture, performance assessment, and others. This meant that a better Education and Training program conducted by the company would improve employee and company performance.
\end{abstract}

\section{Keywords: Education and Training, Employee Performance}

Human resources are the companies' most important assets because of their role as subjects of the implementation of company policies and operational activities. Resources owned by companies such as capital, methods, and machinery cannot provide optimum results if they are not supported by human resources who have optimum performance. Therefore, companies need highperforming employees.
The human factor is prominent for a company considering the competition with one to another company increasingly competitive; this requires a company to work more effectively, productively, and efficiently. The level of competition will make a company able to maintain its survival by giving attention to aspects of human resources in the company because human beings are the focal point for achieving a goal. 
The quality of human resources is determined by the extent to which the system in the field of human resources is able to support and satisfy the desires of both employees and companies. The development of human resources shows a deliberate effort with the aim of changing or increasing the capabilities of the human resources themselves. The enhancement of knowledge, skills, changes in attitude, behavior, and performance deficiencies correction is needed to improve performance and productivity through education and training from the leader or the company. Education and training will provide opportunities for employees to develop new skills and abilities to work so that what is known and mastered now and in the future can help employees understand what is actually done and why it must be done, providing opportunities to add knowledge and expertise. Assessment of the implementation of work carried out by employees or often referred to as performance appraisal, or performance appraisal is also absolutely necessary to see the extent of the success of education and training to these employees. This employee performance appraisal system is the work of employees within the scope of their responsibilities.

The company encounters changes along with the times, changes in the environment, and increasingly high demands. The company is faced with situations and conditions that demand quality human resources, so the company will continue to strive to achieve the goals set in advance. One of the most important things to achieve success in a company's activities does not depend on technology, planning, facilities, and infrastructure, but the important thing is the existence of quality human resources so that it can produce good performance in accordance with the desired goals of the company. This is in line with the concepts proposed by Amstrong and Baron that performance is the result of work that has a strong relationship with the organization's strategic objectives, customer satisfaction and economic contribution (in Fahmi 2014: 128)

The development of an integrated education and training system in relation to efforts to develop general human resources and the development of special employment is indeed a necessity and an increasingly felt need. In fact, although it seems that people are increasingly difficult to manage at present, withdrawal problems, selection, development, and utilization of human resources have been around for thousands of years. These activities are the main part of the work of every manager, managing people who are the basic elements of all organizations, not all abilities needed by the world of work can be obtained from formal schools, this is because the required skills (skills) are needed more specific and focus on what will be assigned, the concept of integrated education and training systems needs to be prioritized for development, with a number of conditions that exist especially in the context of human resource development. The needs are very pronounced, for example job creation, unemployment 
reduction, human resource development, which in turn requires independent professionals and a high and productive work ethic. This is in line with the concept put forward by Priansa (2017: 251) that training is a systematic and planned effort to change or develop new knowledge, skills, attitudes that are appropriate to the needs of public organizations.

Pertamina (formerly known as the State Oil and Natural Gas Mining Company) or the official name of PT. Pertamina (Persero) is an Indonesian Stateowned Enterprises (BUMN); that is tasked with managing oil and natural gas mining in Indonesia. Pertamina was ranked $122^{\text {nd }}$ in the Fortune Global 500 in 2013. Pertamina once had a monopoly on the establishment of gas stations in Indonesia, but the monopoly was abolished by the government in 2001. The company also operates 7 oil refineries with a total capacity of 1,051.7 MBSD, a petrochemical factory with a total capacity of 1,507,950 tons per year, and LPG plants with a total capacity of 102.3 million tons per year.

Pertamina is a joint product of Pertamina and Permina, which was founded on December 10, 1957. This merger occurred in 1968. The president director who served from 2009 to 2014 was Karen Agustiawan, who was appointed by Minister of State-owned Enterprises Syofan Djalil on February 5, 2009, to replace the old Managing Director Ari Hernanto Soemarno. Karen Agustiawan's inauguration made an important history because she became the first woman to successfully occupy the top position in the largest state-owned Indonesian company. Karen Agustiawan resigned as Managing Director on October 1, 2014 and became a professor at Harvard University, Boston, United States. Then on November 28, 2014, President Joko Widodo chose Dwi Soetjipto as President Director of PT Pertamina (Persero). He replaces Karen Agustiawan, who resigned. Pertamina's activities in conducting business in the energy and petrochemical sectors are divided into upstream and downstream sectors and supported by the activities of its subsidiaries and joint ventures. In 2013, Pertamina was ranked 122 out of the world's 500 best Fortune Global companies. In Business development, Pertamina has begun to develop its business both at home and abroad through strategic alliances with partners. Pertamina also has a prospective business in the field of oil and gas drilling services through Pertamina Drilling (PDSI), which has 42 units of land drilling rigs and a subsidiary of PT Usayana, which has 7 land drilling rigs. In gas transmission activities, Pertamina has a gas pipeline network with a total length of $3800 \mathrm{~km}$ and 64 compressor stations

In Gorontalo, PT. Pertamina (Persero) Fuel Oil Terminal (TBBM) is located on J1. Yos Sudarso No.06, Tenda Village, Kota Gorontalo. It was built in 1980 \& operated in 1981 Area of 33,200 $\mathrm{M}^{2}$ with Status of HGB Provincial Government. Gorontalo. Fire Pump Capacity 1500 GPM Fire Pump Capacity 1,200 M3 Foam BPPS 5000 Liter 
Capacity, Jokey Pump Apab 350 \& 150 Lbs Apar and CO2 For Storage Tank Installed Foam Chamber. Hydraulic Winder, LLP warehouse, 30 meters of Service FrOil Boom, 200 Meters of Emergency Deployment Boom, Rubber Boat, Oil Dispersant Pump, Oil Containment Bag, Oil Skimer, Water Ice.

In assessing the employees of PT. Pertamina (Persero) Gorontalo FUEL OIL Terminal, it uses the Key Performance Indicators (KPI) method. Key performance indicators are usually used to measure employee performance at the company as a whole so that the operation head can determine what steps should be taken. Appraisers use the Key Performance Indicators system carried out solely by the operation head, so that no employee knows the value given.

From the results of initial observations and interviews at PT. Pertamina (Persero) Gorontalo Fuel Oil Terminal, there are still employees who do not understand work in several fields such as quality $\&$ quantity because there are still employees who do not understand work in the field of quality \& quantity whose job is to inspect every fuel product that will be received or which will be distributed due to most employees who are appointed do not understand the standards of BBM products to be accepted and which will be distributed. There are still work accidents caused by employees who do not understand and implement the standard operating procedures, there is still a lack of ability of employees to use more modern information technology equipment, there are still fewer employees to carry out the provisions of the rules in doing work on the Sales services \& General Affair who served as sales and administrative services. Based on the existing background, researchers need to raise the title "The Effect of Education and Training on Employee Performance at PT. Pertamina (Persero) Gorontalo Fuel Oil Terminal."

\section{METHOD}

This study employed a quantitative method. The design basically describes the procedures that allow researchers to test the researcher's hypothesis, to be able to reach valid conclusions about the influence or interrelationships between independent variables with the dependent variable in the study. The population in this study were all employees at PT. Pertamina (Persero) Gorontalo Fuel Oil Terminal totaling 102 employees.

\section{RESULT AND DISCUSSION}

Based on the results of regression testing on the SPSS output display, it is known that the regression equation is: $\hat{Y}=$ $24,322+0,561$

From the regression equation obtained, it can be explained that:

\section{Constant Value: 24,322}

From the regression equation obtained, a constant value (constant) applies to the dependent variable, namely employee performance in the Internal Division of PT. PERTAMINA (Persero) GorontaloFuel Oil Terminal is 24,322 units / points, which explains that if all 
the models in the study or independent variables that are used as research benchmarks namely Education and Training $(\mathrm{X})$ programmed by the office carried out by the employee have no effect, then the employee Performance value it is the same as the prevailing constant value, which in this case can be explained that employees who work in the Inner Division have performed quite well before even without being given an Education and Training program. As for if education and training are included in the research model to influence performance, one can see the regression value of the education and training model.

2. Regression Value: 0.561 (Education and Training)
Variable regression value of $\mathrm{X}$ or Education and Training programmed by PT. PERTAMINA (Persero) Gorontalo Fuel Oil Terminal is 0.561 points / unit, which explains that if there is an addition of 1 unit/point from the implementation of Education and Training by employees, such as "Risk and Safety Training is carried out routinely every year, and education and training programs are required to be followed by all employees ", it will add value employee performance at PT. PERTAMINA (Persero) Gorontalo Fuel Oil Terminal, which previously was 24,322 and will increase by 0.561 points.

Table 1. Simple Regression Analysis Test

\begin{tabular}{|c|c|c|c|c|c|c|}
\hline \multicolumn{7}{|c|}{ Coefficients $^{\mathrm{a}}$} \\
\hline & & \multicolumn{2}{|c|}{$\begin{array}{l}\text { Unstandardized } \\
\text { Coefficients }\end{array}$} & \multirow{2}{*}{\begin{tabular}{|l|}
$\begin{array}{l}\text { Standardized } \\
\text { Coefficients }\end{array}$ \\
Beta \\
\end{tabular}} & \multirow[t]{2}{*}{$t$} & \multirow[t]{2}{*}{ Sig. } \\
\hline \multicolumn{2}{|c|}{ Model } & $\mathrm{B}$ & Std. Error & & & \\
\hline \multirow[t]{2}{*}{1} & (Constant) & 24.322 & 10.180 & & 2.389 & 0.024 \\
\hline & $\begin{array}{l}\text { Education and } \\
\text { Training }\end{array}$ & 0.561 & 0.157 & 0.560 & 3.576 & 0.001 \\
\hline
\end{tabular}

\section{Source: SPSS (2019)}

\section{Hypothesis Test / $t$-Test (partial)}

To find the value of $t$ table, it depends on the amount of df (degree of freedom) and the level of significance used. By using a significance level of 5\% and a df value of $n-k-1=30-1-1=28 \mathrm{t}$ table value of 1.701 was obtained. Based on these references, the test is based on the results of $\mathrm{t}$ count of each independent variable on t table. As the SPSS output display in table 4.9 , the t-value obtained for the Education and Training variable is 3.576 with a significance value of 0.001 . Based on this, it can be concluded that the calculated $t$ value is greater than the table value (3.576> 1.701). And the significance 
value (0.001) is lower than the alpha probability value (0.05). From these explanations, it can be concluded that the research hypothesis was accepted or $\mathrm{H} 0$ was rejected and $\mathrm{Ha}$ was accepted or explained that partially or individually the variable Education and Training conducted by PT. PERTAMINA (Persero) Gorontalo Fuel Oil Terminal has a positive and significant influence on employee work performance.

Table 2. T-test

\begin{tabular}{|c|c|c|c|c|c|c|}
\hline \multicolumn{7}{|c|}{ Coefficients $^{\mathbf{a}}$} \\
\hline \multirow{2}{*}{\multicolumn{2}{|c|}{ Model }} & \multicolumn{2}{|c|}{$\begin{array}{l}\text { Unstandardized } \\
\text { Coefficients }\end{array}$} & \multirow[t]{2}{*}{$\begin{array}{l}\text { Standardized } \\
\text { Coefficients }\end{array}$} & \multirow{2}{*}{$\mathrm{T}$} & \multirow{2}{*}{ Sig. } \\
\hline & & B & $\begin{array}{l}\text { Std. } \\
\text { Error }\end{array}$ & & & \\
\hline 1 & (Constant) & 24.322 & 10.180 & & 2.389 & 0.024 \\
\hline & TRAINING & 0.561 & 0.157 & 0.560 & 3.576 & 0.001 \\
\hline
\end{tabular}

Source: SPSS (2019)

\section{CONCLUSSION}

Based on the results of the study, the following conclusions can be drawn:

1. Each indicator that contains statements that represent research variables namely Education and Training, and employee performance variables at PT. PERTAMINA (Persero) Gorontalo Fuel Oil Terminal has good instrument reliability and consistent answers from respondents.

2. The hypothesis compiled is proven that partially (t-test), that the Education and Training carried out by PT. PERTAMINA (Persero) Gorontalo Fuel Oil Terminal has a significant effect on the performance of its employees.

3. Education and training variables affect the increase in work produced by employees so that employees better understand the work they do.

4. Education and training variables have a contribution to affect the performance of employees at PT. PERTAMINA (Persero) Gorontalo Fuel Oil Terminal and the rest are influenced by other variables not examined, such as compensation, work culture, communication performance evaluation, and so on.

\section{SUGGESTION}

Based on the conclusions of the study, researchers suggest:

1. To other company institutions, especially PT. PERTAMINA (Persero) Gorontalo Fuel Oil Terminal can pay attention to aspects that can improve employee performance and improve company performance through 
Education and Training Programs for its employees that aim to develop employee knowledge and skills in mastering their work.

2. This research can be useful as information and reference material, both for companies, academics, and other parties, who discuss the practice of human resource management in companies, especially regarding Education and Training, and Employee Performance.

3. It is expected that this research can be used as a reference/reference for other parties to be able to add sample criteria to be respondents of the study, or add other variables and test their effects on employee performance, in order to enrich the results of research.

\section{REFERENCESS}

Fahmi, Irham,2014.Manajemen Teori, Kasus, dan Solusi. cetakan keempat.Bandung. Alfabeta
Fahmi, Irham, 2014. Perilaku Organisasi Teori, Aplikasi, dan Kasus. Cetakan Kedua. Bandung. Alfabeta

Handoko, Hani, 2013. Manajamen personalia dan sumberdaya manusia. edisi2

Priansa, Donni. 2017. Manajemen Pelayanan Prima. Bandung. Alfabeta

Sagala, Syaiful. 2008.Konsep dan Makna Pembelajaran. Bandung. alfabeta

Sudiro ahmad. 2009.Pengaruh komitmen pengorganisasian dan kepuasan kerja terhadap kinerja tenaga edukatif/ dosen (Studi Di Universitas Brawijaya Malang), Jurnal aplikasi/ volume7/nomor/ Februari 2009

Sulistiyani, Ambar. Manajemen Sumber Daya Manusia. Cetakan pertama. Gava Media. Yogyakarta

Syarifuddin \& Nurmawati. 2017. Pengelolaan Pendidikan. Medan. Perdana Publishing. 